\title{
Seasonal Uptake of Nutrients by Chenin blanc in Sand Culture:
}

\section{Nitrogen}

\author{
W. J. CONRADIE \\ Oenological and Viticultural Research Institute, Private Bag X5026, Stellenbosch 7600
}

The author wants to express his thanks and appreciation to Miss D. M. Dwyer for general assistance and analyses of the samples.

\begin{abstract}
The seasonal uptake and the distribution of nitrogen were determined for Chenin blanc/99R, grown in sand culture under South African conditions. Whole vines were sampled 14 times in the course of one year.

Two distinct absorption peaks were found-the first starting after bud burst and lasting up to véraison, while the second extended from harvest into the leaf fall period. The amount of nitrogen absorbed during the second (post harvest) period amounted to $34 \%$ of the total for the season, and most of this was stored in the roots.

The amount of nitrogen removed by the crop $(1,39$ $\mathrm{kg} /$ ton of grapes) compared well with relevant literature, but the amount of nitrogen in leaves and canes associated with this, differed from results obtained in other countries.
\end{abstract}

\section{INTRODUCTION}

The vine is generally more likely to respond to nitrogen (N) than to phosphorous $(\mathrm{P})$ and potassium $(\mathrm{K})$ fertilization (Williams, 1946). The effect of $\mathrm{N}$ fertilizers on grape yield and quality has been extensively evaluated. However, in many cases little or no beneficial effect on yield could be detected (Bucher, 1969; Tulloch \& Harris, 1970; Marocke, Balthazard \& Huglin, 1977). This led to the concept of a " soil bank', where the quantity of nutrients removed by the crop should be replaced annually (Cook, 1966). At present, the philosophy on vine fertilization is changing because it is recognized that some soils contain chemical reserves capable of supplying nutrients for hundreds of years. However, to carry out any realistic fertilization programme, it is still essential to know the amount of nutrients removed by the crop. With this object in mind many workers from as far back as the nineteenth century calculated the amounts of nutrients removed from the soil during the production of a crop of a specific size (Müntz, 1895, as reported by Perold, 1927; Alexander, 1957; Condei \& Dumitrescu, 1968; Finkenauer, 1975; Marocke, Balthazard \& Correge, 1976).

There were appreciable differences between the values reported for the different localities, and none can be regarded as representative of South African conditions. Furthermore, in most cases analyses were confined to aerial growth only. Where roots were also taken into account, it was done only on a qualitative basis (Alexander, 1957). This is regarded as a serious deficiencyespecially in hot countries like South Africa, where very active root growth during the long period between harvest and leaf fall is possible.

The optimum time for the application of nitrogen will depend on the period of peak demand by the vine, and $\mathrm{N}$-leaching from the soil. The periods were determined by several workers (Hiroyasu, 1961; Guillén, Fernández \& Caro, 1965; Lafon, Couillaud, Gay-Bellile \& Lévy, 1965; Christensen, 1969; Gärtel, undated, as reported by Huschka, 1978). Investigations were mainly conducted on the aerial growth, and were confined to the growing season. The quantitative way in which $\mathrm{N}$-reserves were utilized over a whole season was therefore not quite clear-especially for the warmer countries.

The N-content of vine leaves (blades and/or petioles) is generally believed to give a good indication of the state of N-nutrition of the vine (Winkler, Cook, Kliewer \& Lider, 1974). However, interpretation of analytical figures is rendered difficult through seasonal changes in $\mathrm{N}$-content of blades and petioles (Lafon et al., 1965; Christensen, 1969; Cummings, 1977).

Locally, seasonal variations in the $\mathrm{N}$-content of blades were determined by Beyers, Pienaar \& Terblanche (1968), but their work was confined to table grapes, which are grown under completely different conditions, while petioles $_{{ }_{s}}$ were not analyzed separately-with the result that local standards for leaf composition are incomplete.

In order to establish the nutrient uptake pattern under the climatic conditions of the traditional wine areas of the Western Cape, an experiment in sand culture was carried out using the most commonly planted grape variety, Chenin blanc, as test plant. This report only deals with changes in dry mass of organs and with the uptake of $\mathrm{N}$.

\section{MATERIALS AND METHODS}

One year old Chenin blanc (Vitis vinifera) vines, grafted on $99 \mathrm{R}$ rootstock, were planted in $45 \ell$, glazed, earthenware pots during September 1974 and kept out of doors. The growth medium consisted of coarse grade, acid washed quartz sand, and the pots were placed in trenches in order to ensure rootzone temperatures comparable to that of the surrounding soil. The vines were fed with Hoagland's standard solution (Hoagland \& Arnon, 1950), and shoots were supported on a 3-wire Perold trellis (Zeeman, 1978). After one season the vines were pruned back to two 4-node spurs, and eventually 8 shoots were retained on each vine. During the second growing season the vines were sampled 14 times at the stages indicated in 
Table 1. For sampling purposes the vines were divided into 8 blocks of 14 vines each. At each sampling date a vine was selected randomly from every block, removed from the pot, washed free of sand and, depending on the growth stage, separated into the following parts and organs: Rootstock, bark on rootstock, trunk (one to two year old scion wood including the graft union), bark on trunk, medium roots (diameter $>2 \mathrm{~mm}$ ), fine roots (diameter $<2 \mathrm{~mm}$ ), new shoots, bark on new shoots, leaf blades, leaf petioles, marc (skins, pips and stalks) and juice. During leaf fall, the fallen leaves were collected regularly. All samples (excluding juice) were washed according to the method described by Beyers (1962), subsequently dried at $60{ }^{\circ} \mathrm{C}$, the mass determined, and milled to pass a 20 mesh screen. In the case of juice the volume was determined, total soluble solids measured, and the amount of dry material calculated. Total $\mathrm{N}$ was determined in a selenious acid/sulphuric acid digest by means of an automated colorimetric method as described by Warner \& Jones (1970).

\section{RESULTS}

Plant Performance: Root zone temperatures in the pots compared well with that reigning in the surrounding soil (not shown). During the active growing season daily mean temperatures of the soil were slightly higher than those measured in the pots. The largest difference which occurred in February amounted to $2,5^{\circ} \mathrm{C}$. However, during the winter months (May, June, July and August) sand temperatures were marginally higher than those of the surrounding soil-the largest difference of $1,2{ }^{\circ} \mathrm{C}$ occurring during August. These small differences did not affect the times of bud burst, bloom and leaf fall of the experimental vines, which corresponded well with those of commercial Chenin blanc vineyards. However, difficulty was experienced to obtain a high sugar content in the grapes, and harvesting took place at $16,6{ }^{\circ} \mathrm{B}$ when the sugar content appeared to have reached a plateau. Grapes were of good quality as evaluated visually.

Accumulation Of Dry Material: The seasonal changes in dry mass of the various organs of the vine, are shown in Table 1 and Fig. 1. (For greater simplicity, medium and fine roots were combined and indicated as roots, while juice and marc were combined as bunches.)

On the first sampling date, dormant stage, the roots accounted for $65 \%$ of the dry mass of the vine. Up to bloom no appreciable increase in the total dry mass of the vine was noted. The increase in dry material due to new growth was cancelled by a significant decrease in the dry mass of the roots. During the $21 \mathrm{~d}$ period of bloom, the dry mass of the vine increased significantly by an amount of $105,4 \mathrm{~g}$. The vine was now self sufficient, and apart from the increase in dry mass of the vegetative organs, the permanent parts also showed increases. This pattern became more pronounced as véraison was approached. During the $64 \mathrm{~d}$ from the end of bloom to veraison, the dry mass of the vine increased by $423 \mathrm{~g}$, which represented about $49 \%$ of the amount gained over one season. During the $35 \mathrm{~d}$ preceding harvest the rate of dry mass increase slowed down to show a gain of only $123,9 \mathrm{~g}$. During the same period the mass of the bunches increased by $145 \mathrm{~g}$, thus implying a loss of about $20 \mathrm{~g}$ in dry mass of the vine itself, which could again be traced back to the roots. At this stage the bunches contained $47,1 \%$ of the dry material in the vine, the vegetative growth (new shoots and leaves) $28,2 \%$, and the permanent parts (trunk, rootstock and roots) $24,7 \%$.

During the $33 \mathrm{~d}$ period following harvest there was a further significant increase in the dry mass of the vine, mainly the result of a massive increase in the dry mass of the roots.

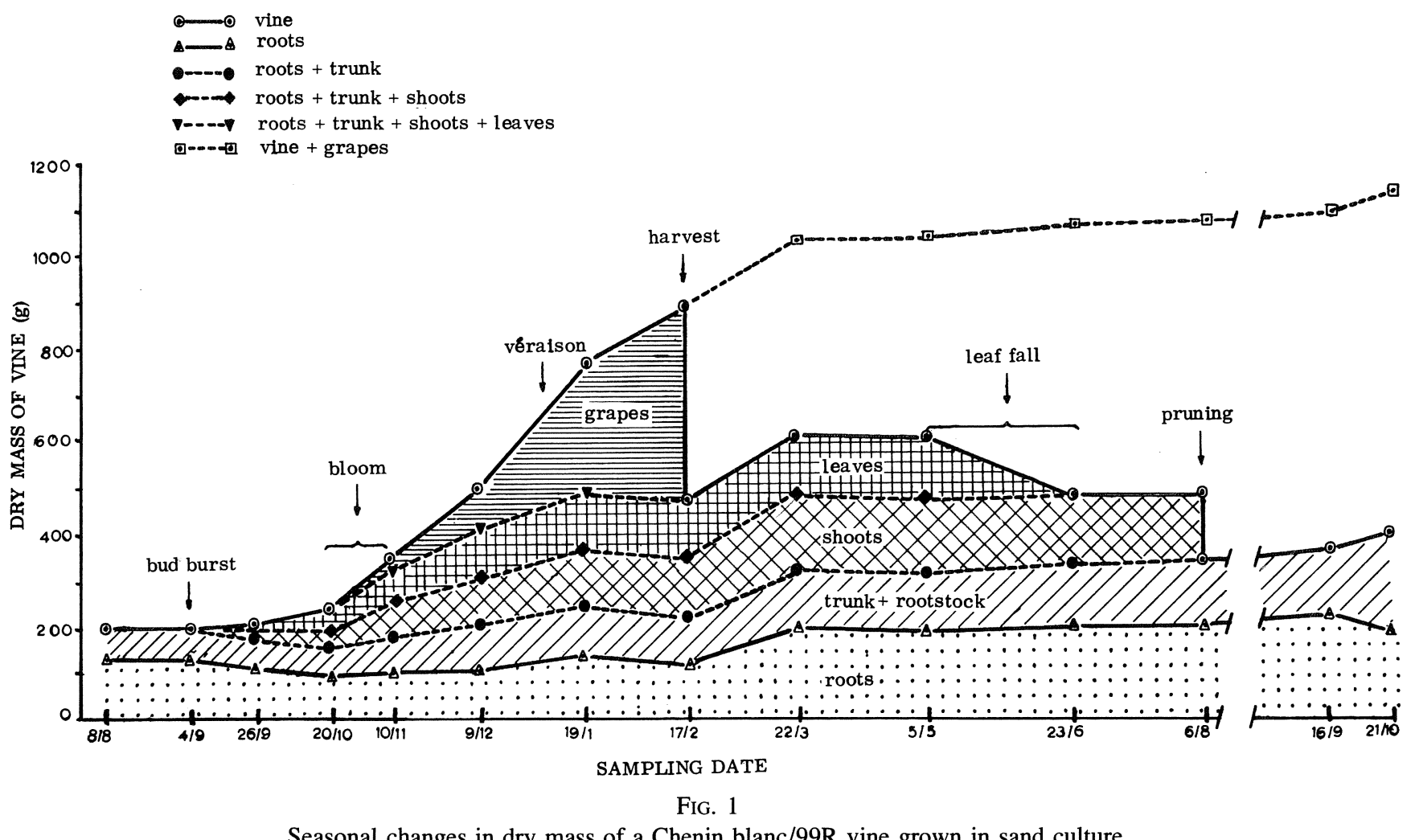

Seasonal changes in dry mass of a Chenin blanc/99R vine grown in sand culture. 
TABLE 4

Amounts of dry material and $\mathrm{N}$ accumulated by the various organs of Chenin blanc/99R during the production of 1 ton of grapes

\begin{tabular}{|c|c|c|c|c|}
\hline $\begin{array}{l}\text { Part of vine } \\
\text { Grapes } \ldots \ldots \ldots \ldots \ldots \ldots \ldots \ldots \ldots \ldots \ldots \ldots \ldots \ldots \ldots \ldots \ldots \ldots \ldots \ldots \ldots \ldots \ldots \ldots \ldots \ldots \ldots \ldots\end{array}$ & \multicolumn{2}{|c|}{$\underset{(\mathrm{kg})}{\text { Mass of dry material }}$} & \multicolumn{2}{|c|}{$\begin{array}{l}\text { Nitrogen required } \\
(\mathrm{kg})\end{array}$} \\
\hline 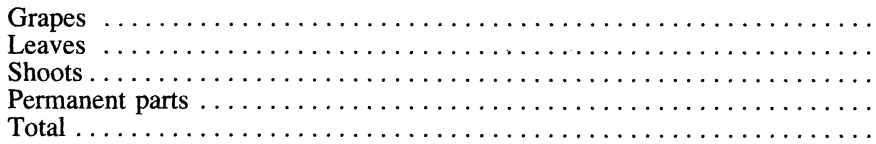 & $\begin{array}{r}162 \\
65 \\
54 \\
52 \\
333\end{array}$ & $\begin{array}{r}48,4 \\
19,6 \\
16,3 \\
15,7 \\
100\end{array}$ & $\begin{array}{l}1,39 \\
1,21 \\
0,56 \\
0,73 \\
3,89\end{array}$ & $\begin{array}{l}35,8 \\
31,1 \\
14,4 \\
18,7 \\
100\end{array}$ \\
\hline
\end{tabular}

amounted to $3,7 \mathrm{~kg}$. However, the local figures correspond well with the estimated amount of $2,1 \mathrm{~kg}$, as obtained elsewhere in France by Lafon et al. (1965).

The permanent parts of the vine accumulated $0,73 \mathrm{~kg}$ $\mathrm{N} /$ ton of grapes (Table 4). Thus, if all leaves and prunings are returned to the soil, a crop of 1 ton of Chenin blanc grapes may be expected to remove $2,1 \mathrm{~kg}$ of $\mathrm{N}$ from the soil per year.

\section{DISCUSSION}

Under the conditions of this experiment Chenin blanc/ 99R showed two distinct nitrogen absorption peaks. The first started after bud burst, and lasted up to véraison. The practical implication of this is that $\mathrm{N}$-fertilizers should not be applied too early in spring in the coastal region (not before August/September), as heavy winter and early spring rain could cause the nitrogen to be leached out of the root zone by the time active absorption starts. During the second absorption period (post harvest) active root growth occurred, and the amount of $\mathrm{N}$ accumulated during this stage amounted to $34 \%$ of the seasonal total. This emphasizes the importance of post harvest fertilization if moisture is available in the form of early rains or irrigation. In colder countries with a shorter growing season, where the harvest more or less coincides with leaf fall, post harvest fertilization may be expected to be of less importance.

The importance of roots as storage organs for N-reserves was emphasized by the seasonal pattern (Fig. 2). Except for a short period preceding véraison, the roots lost nitrogen during the whole period up to harvest. After harvest, the roots were actively accumulating $\mathrm{N}$, and this process went on into the stage of leaf fall-even though the roots stopped active growth about 5 weeks after harvest, as indicated by the dry mass (Fig. 1).

The amount of nitrogen removed by the crop compares well with figures reported by other workers in France (Müntz, 1895, as reported by Perold, 1927; Lafon et al., 1965), but the nitrogen demand of the vegetative growth differed appreciably. For example in Alsace (Marocke et al., 1976) the vegetation contains a larger $(69 \%)$ fraction of the nitrogen than in South Africa (56\%), whereas figures reported for the western district of Charente (Lafon et al., 1965) are in better agreement with the local results $(60 \%)$.

Seasonal changes in the nitrogen content of leaf blades and petioles (Table 3 ) illustrated the difficulties encountered with the interpretation of leaf analyses. In the case of the blades, the $\mathrm{N}$ concentration decreased from $3,62 \%$ at the start of bloom to $2,60 \%$ at harvest, followed by a further drop to $1,88 \%$ at the start of leaf fall. The $\mathrm{N}$ content of the petioles remained much more stable, and after an initial drop during the bloom period $(1,71 \%$ to $0,96 \%$ ) the nitrogen level remained relatively stable, and a $\mathrm{N}$-concentration of $0,9 \%$ appeared to be normal under the conditions of this experiment. This figure compares well with the $1,06 \%$ reported by Bergman, Kenworthy, Bass \& Benne (1958) for Concord grapes grown in sand culture. However, as mentioned by Cummings (1977) it is difficult to draw definite conclusions when comparing these figures with other published data, on account of variations in soils and climate.

An appreciable amount of the yearly accumulation of both dry material and nitrogen can be attributed to the permanent parts $(15,7 \%$ and $18,7 \%$ respectively). For older vines these proportions may be less, but even so this constitutes a factor which must be taken into account in estimating fertilizer requirements.

\section{REFERENCES}

ALEXANDER, D. McE., 1957. Seasonal changes in the nitrogen content of the sultana vine. Aust. J. agric. Res. 8, 162-178.

AMIRDZANOV, A. G., 1970. Assimilation of N, P and K by vines during the growing season. Fiziol. Biohim, Kultur Rast. 2, 533-539. (Abstr.: Hort. Abstr. 41, 8 660, 1971).

BERGMAN, E. L., KENWORTHY, A. L., BASS, S. T. \& BENNE, E. J., 1958. A comparison between petiole and stem analyses of Concord grapes. Proc. Amer. Soc. Hort. Sci. 71, 177-182.

BEYERS, E., 1962. Diagnostic leaf analysis for deciduous fruit. S. Afr. J. agric. Sci. 5, 315-329.

BEYERS, E., PIENAAR, W. J. \& TERBLANCHE, J. H., 1968. Seasonal trends in leaf composition of deciduous fruit. The Deciduous Fruit Grower 18, 87-92.

BUCHER, R., 1969, Ergebnisse eines neunjährigen Rebdüngungsversuchs über die Wirkung steigender Stickstoffund Spurenelementgaben auf die Menge und Güte der Trauben und Möste sowie auf die Aufnahme von Makro und Mikronährstoffen durch die Rebe. Weinberg $u$. Keller 16, 227-252.

CHRISTENSEN, P., 1969. Seasonal changes and distribution of nutritional elements in Thompson Seedless grapevines. Amer. J. Enol. Vitic. 20, 176-190.

CONDEI, G. \& DUMITRESCU, F., 1968. Contribution to the determination of the nutrient requirements of vines and equilibrium between the major elements. An Inst. Vitic. Vinif. 1, 199-214. (Abstr.: Hort. Abstr. 40, 719, 1970).

COOK, J. A., 1966. Grape Nutrition. In: Childers, N. F. (Ed.): Fruit Nutrition, 777-812. Horticultural Publications, New Jersey.

CUMMINGS, G. A., 1977. Variation in the concentration of certain elements in Muscadine grape leaves related to season, leaf portion, and age. J. Amer. Soc. Hort. Sci. 102, 339-342.

FINKENAUER, K., 1975. Aktuelle Düngungsprobleme im Weinbau. Dt. Weinbau 30, 725-726.

GUILLÉN, M. G., FERNÁNDEZ, F. G. \& CARO, M., 1965. Seasonal variation in the nutrient content of the leaves of fruit trees. An Edafol. Agrobiol. 24, 327-341. (Abstr.: Hort. Abstr. 36, 543, 1966)

HIROYASU, T., 1961. Nutritional and physiological studies on the grapevine. J. Jap. Soc. Hort. Sci. 30, 111-116. (Abstr.: Hort. Abstr. 32, 2 677, 1962). 
HOAGLAND, D. R. \& ARNON, D. I., 1950. The water culture method for growing plants without soil. Calif. Agric. Expt. Sta. Circ. 347.

HUSCHKA, H., 1978. Standortgerechte Düngung der Reben. Rebe \& Wein 31, 16-19.

LAFON, J., COUILLAUD, P., GAY-BELLILE, F. \& LÉVY, J. F., 1965. Rythme de l'absorption minérale de la vigne au cours d'un cycle végétatif. Vignes et Vins 140, $17-21$.

MAROCKE, R., BALTHAZARD, J. \& CORREGE, G., 1976. Exportations en éléments fertilisants des principaux cépages cultivés en Alsace. C. R. Agriculture, 420-429.

MAROCKE, R., BALTHAZARD, J. \& HUGLIN, P., 1977. Données concernant les exportations en éléments fertilisants de la vigne et un essai de fumure. Les Vins d'Alsace 5, pages centrales.
PEROLD, A. I., 1927. A treatise on viticulture, Chapter 9. The Macmillan Company, New York.

TULLOCH, H. W. \& HARRIS, W. B., 1970. Fertilizer responses with non-irrigated Shiraz grapevines. Aust. $J$. agric. Res. 21, 243-252.

WARNER, M. H. \& JONES, J. B., 1970. A rapid method for nitrogen determination in plant tissue. Soil Sci. Plant Anal. 1, 109-114.

WILLIAMS, W. O., 1946. California vineyard fertilizer experimentation. Proc. Amer. Soc. Hort. Sci. 48, 269-278.

WINKLER, A. J. COOK, J. A., KLIEWER, W. M. \& LIDER, L. A., 1974. General Viticulture. University of California Press.

ZEEMAN, A. S., 1978. Effect of rootstocks on the performance of Chenin blanc under various environmental conditions. Proc. S. Afr. Soc. Enol. Vitic., 71-86. 